\title{
The Fascination of André Breton for the Arithmosophic Calculation in Arcane 17 (The Number 1713 and Gérard de Nerval)
}

\section{Spomenka Delibasic}

Department of French Language and Literature, Faculty of Philology, University of Montenegro, Niksic, Montenegro

\section{Email address:}

spomenkadel@yahoo.fr

\section{To cite this article:}

Spomenka Delibasic. The Fascination of André Breton for the Arithmosophic Calculation in Arcane 17 (The Number 1713 and Gérard de Nerval). International Journal of Literature and Arts. Vol. 7, No. 5, 2019, pp. 98-104. doi: 10.11648/j.ijla.20190705.12

Received: August 2, 2019; Accepted: September 4, 2019; Published: September 19, 2019

\begin{abstract}
In surrealist researches and writings, recourse to the occult and the hermetic tradition goes hand in hand with the valorization of a set of esoteric knowledge which gathers at the same time mysticism, alchemy, arithmosophy and fictions which make an important place for mystery and the supernatural. Breton devoted himself from his first works to esoteric orientation and hermetism, consubstantially united with his poetry. We evoke the Breton text - Arcane 17, which has as its theme the arithmosophic calculation on its date of birth and that of Gerard de Nerval and, since no methodology can exhaust the meaning of this text, extremely rich in intertextual references, in images symbolic, mythical, in metalogisms, we propose to approach a methodologically open approach that gives absolute priority to the text. The presence of occultism and arithmosophy in Arcane 17, as indeed in all the other surrealist texts dealing with these domains, refers in fact to their poetic aspects. A set of Breton texts (Arcane 17, Le Surréalisme et la peinture, Perspective cavalière, Les Entretiens) invite us to examine how this author treats esoteric thought as the possibility of a deployment of reverie and poetic inspiration. This corpus attests, certainly, Breton's concern for the deep links between numbers, letters and events as signs to be deciphered in his spiritual approach and remains an inspiration to the most innovative sensibilities of modernity. Breton was fascinated by the number 1713 (his initials A. B. constitue, by a precise graphical game, an equivalent by transforming the figures; in the text "Du poème-objet", Breton reflects at length on the historical and scientific events related to this year) and refers explicitly several times to Pythagoreanism and Gerard de Nerval. The aim of this article is to show that the persistent vitality of an esoteric conception on the world and on the human understanding that surrealism has always proposed itself contemplates the possible actuality of some aspects of Breton's thought, such as evidenced by a recent study by Patrick Lepetit The Esoteric Secrets of Surrealism: Origins, Magic, and Secrets Societies (2014).
\end{abstract}

Keywords: André Breton, Esotericism, Arithmosophy, Arcane 17, Gérard de Nerval, 1713

\section{Introduction}

"We can even ask ourselves what is the nature of the interest that some members of the group and its immediate circle, namely Breton himself, displayed for numbers. Breton could see the number 1713 in the initials of his name, and underscored that it is the date of the publication of George Berkeley's Dialogues between Hylas and Philonous, which includes the water fountain mentioned in Nadja. And he concludes Arcanum 17 with these lines:

Eternal youth. "1808 = 17:" birth of Nerval. Publication of the Theory of Four Movements and the General Destinies.
Man Ray signed some of his drawings with a 11112, which is the stylized representation of his own initials. [...] Queneau, a trained mathematician, also granted a particularly noteworthy importance to the symbology of numbers, as Marie-Noëlle Campana-Rochefort clearly demonstrated in her paper titled "The Numbers in The Blue Flowers." After pointing out that "The Blue Flowers, through a precise numerical architecture, expresses an entire traditional or Eastern cosmogony metaphorically," and to be exact makes reference to Plato and the "I Ching," she lists names, the majority of which are memorable.

This permanence of number takes part in a literary 
tradition that was revived by Queneau and defended by Dante or Butor, with the help of Victor Hugo, Baudelaire, Balzac, and others: the number is a much more powerful sign than the linguistic sign. While words succeed at explaining the world, the number is their secret root [1]."

(Patrick Lepetit, The Esoteric Secrets of Surrealism: Origins, Magic, and Secret Societies)

From the first emergence of Surrealism, we see a main characteristic of movement appearing corresponding to a set of four fundamental themes or rather four essential dynamics that involve a set of literary, philosophical and cultural references from a rich cultural heritage accumulated on several centuries - the metaphysical tradition and its esoteric implications, the libertarian rupture with norms and rational rules, the valorization of adventure and quest, the resurgence of unknown precursors. These four dynamics are not always explicitly linked, but their co-occurrence nevertheless responds to a deeper logic: they are indeed present simultaneously in Breton's work and sometimes even in the surrealist movement.

From his earliest works, Breton devoted himself to esoteric orientation and metaphysical tradition: from Les Champs Magnétiques (1920), the first surrealist document of the presurrealist period, to the last collection of texts, La Clé des Champs (1953). The imprint of the occult sciences and the use of esotericism can be found, passim, in several writings, to mention only a few: Nadja (1928), the Second Manifeste du surréalisme (1930), L'Amour fou (1937) and Arcane 17 (1944).

Richard Danier sees in Breton's works: Nadja, L'Amour fou and Arcane 17 "a homogeneous trilogy, the symbolic triangle in which André Breton's alchemical message is inscribed [2]" and adds that the alchemical code, very closely linked "to the evolution of the personality of Breton [...] culminates and ends in Arcane 17 [3]." Suzanne Lamy in her doctoral thesis entitled André Breton, Hermétisme et Poésie dans Arcane 17, notes that Nadja and L'Amour fou are already a novelty "by juxtaposing didactic prose, poem, stories and photographs [4]" and that the text of Arcane 17 "is indeed the ultimate part of the immense text that began with Nadja" [4].

The text of Arcane 17 formulates a number of problems, notably those of literary theory and those of the status of the text - essay [5], narrative, poetic prose or work of personal literature?

Regarding the categories to which surrealist prose could belong, Laurent Jenny writes: "The open contempt of Surrealism for the romantic and anecdotal does not incline to speak of "narrative", and prose texts, for want of a more precise qualification, remain located in an indistinct domain of "poetics". [...] Only poetic criteria can confirm or not the existence [...] of a purely surrealist narrative discourse, involving an original work on writing [6]."

If one adopts the structuralist approach, his methods are not operational for works which, like Arcane 17, "are simililar to serial and open works [7]." Regarding the narrative seriality, Umberto Eco had already warned in his work La Structure absente of an incompatibility with the methods of textual structuralism: "The tools that structuralism offers us to analyze a structure can they coexist with the notions of versatility and seriality [8]?" The problem with the application of the processes of structural analysis to literary text such as this one is that this work simultaneously brings together the "three major types of discourse: metonymic (narrative), metaphorical (lyrical poetry, sapiential discourse), enthymmatic (intellectual discourse) [9]."

To better study the original characteristic of Arcane 17, we must emphasize "the deployment of the plural aspect of the text, its semi-open character, the fact that it lacks a unitary meaning, that several discourses are based on it [10]", taking into account the domain of esotericism and hermetism in all their forms: Hermetic Cabal, High Magic, Alchemy, Theosophy, Arithmosophy.

\section{Arcane 17 and Arithmosophy}

We will refer to the Breton text - Arcane 17 which has as its theme the arithmosophic calculation of his date of birth and that of Gérard de Nerval and, since no methodology can exhaust the significance of this text, extremely rich in intertextual references, in images symbolic, mythical, in metalogisms, in extended metaphors [11], we propose to approach a methodologically open approach that gives absolute priority to the text.

Completed to print December 30, 1944 and published around March of 1945 in New York at Brentano's, the novel Arcane 17, which relates the journey of Breton in Canada with Elisa ${ }^{1}$ between August and October 1944 (more precisely from August 20 to October 20, 1944, as Breton noted at the bottom of the text) from Gaspésie to the Laurentians ${ }^{2}$ explicitly refers several times to Gérard de Nerval and the interpretation of numbers. Considered as a secret text that is given as if to be decoded, as requiring a double reading, as covering a double discourse: one of surface, manifests the other of depth, this palimpsest tissue is explicitly part of the "golden furrow" [12] of the Esoteric Tradition and is defined as the product of a specific arrangement - "all fortuitous arrangement" [13] - of a series of references borrowed from other texts.

Through the interview ${ }^{3}$ (XV. - DE QUELQUES ESPÉRANCES ABUSIVES. - À PARIS LE SURÉALISME DOIT DÉJOUER DIVERSES MANEUVRES

\footnotetext{
1 At the end of 1943, Breton met Elisa Claro at Larré's restaurant in New York, who was none other than Elisa, the dominant figure in Arcane 17. That same year, Elisa was cruelly affected by the accidental death of her only seventeen-year-old daughter.

2 The names of the villages during the trip in Gaspésie: Saint-Anne, Gaspé, Île Bonaventure, bird sanctuary, the Laurentians of Montreal, Sainte-Marguerite and Sainte-Agathe-des-Monts.

3 André Breton conducted a series of radio interviews with André Parinaud (sixteen French Radio broadcasts), broadcast on the national channel from March to June 1952. Written and recorded in 1951, Les Entretiens de Breton avec André Parinaud was broadcast from February to June 1952 in the evening on the National Program.
} 
D’OBSTRUCTION. - GAGES DE SA VITALITÉ.), Breton clarifies the meaning of his book Arcane 17 and evokes the hopes of political and social renewal related to the period of the liberation of Paris.

To André Parinaud's question:

"Avant d'aborder l'élément essentiel de cet entretien - les positions surréalistes depuis la Libération - je souhaiterais que vous me précisiez les raisons symboliques et personnelles qui vous ont amené à choisir le titre de l'ouvrage qui opère la transition entre deux époques; Arcane 17 [14]

Breton replied:

"Ce titre Arcane 17 se réfère directement à la signification traditionnelle de la lame de tarot qui s'intitule "L'Étoile". C'est l'emblème de l'espérance et de la résurrection. [...], les nouveaux temps qui s'annonçaient à partir de la libération de Paris, telle que la nouvelle, exaltée au possible, pouvait alors m'en parvenir, m'eussent, à eux seuls, incliné à placer mon ouvrage sous ce signe. Mais il est certain que, dans mon esprit, il se trouvait surdéterminé par la présence auprès de moi d'un être infiniment cher pour qui, peu avant notre rencontre, je savais que la vie avait perdu toute raison d'être - que je n'aspirais donc à rien tant qu'à faire "revenir à la vie". C'est à la conjonction, exceptionnelle de sentiments d'ordres si distincts dont j'étais le siège que j'ai demandé de m'éclairer l'autre sens de cet "Arcane 17" qui, pour les occultistes, n'est autre que la sensibilité comme germe de la vie intellectuelle. La vie intellectuelle qui allait renaître - libre de contraintes, on pouvait du moins l'espérer - il s'agissait de savoir quelle sensibilité rénovée, réinvestie de ses pouvoirs primitifs, était susceptible de la promouvoir. À la fin de cet été 1944 où mes yeux s'ouvraient sur la côte de Gaspésie et son île - au nom si invitant - de Bonaventure au loin, les circonstances m'étaient propices pour opérer une reconnaissance aux confins de ces terres du désir longtemps dévastées mais brusquement admises à recouvrer leur sève, dont je n'avais jamais cessé de subir l'appel, même quand elles me paraissaient le plus hors d'atteinte; la poésie, l'amour, la liberté [15]."

Responding in 1956 to an inquiry into the link between Surrealism and Tradition, Breton repeats this phrase from Arcane 17: "I was able to say in Arcane 17 that, consciously or not, the process of artistic discovery is dependent on the form and means of progression of high magic but I was careful to add that it remains foreign, more often than not, to all of its metaphysical (or religious) ambitions [16]."

The work of Breton attests, certainly, his concern for the deep links between numbers, letters and events as signs to be deciphered. We know that Breton was fascinated by the number 1713 and that his A. B. initials constitute, through a precise graphic game, an equivalent by by transformation of the numbers.

On August 5, 1931, Breton sent a postcard "Figure 1" from Tinchebray to Paul Éluard, 42 rue Fontaine, with only three lines:

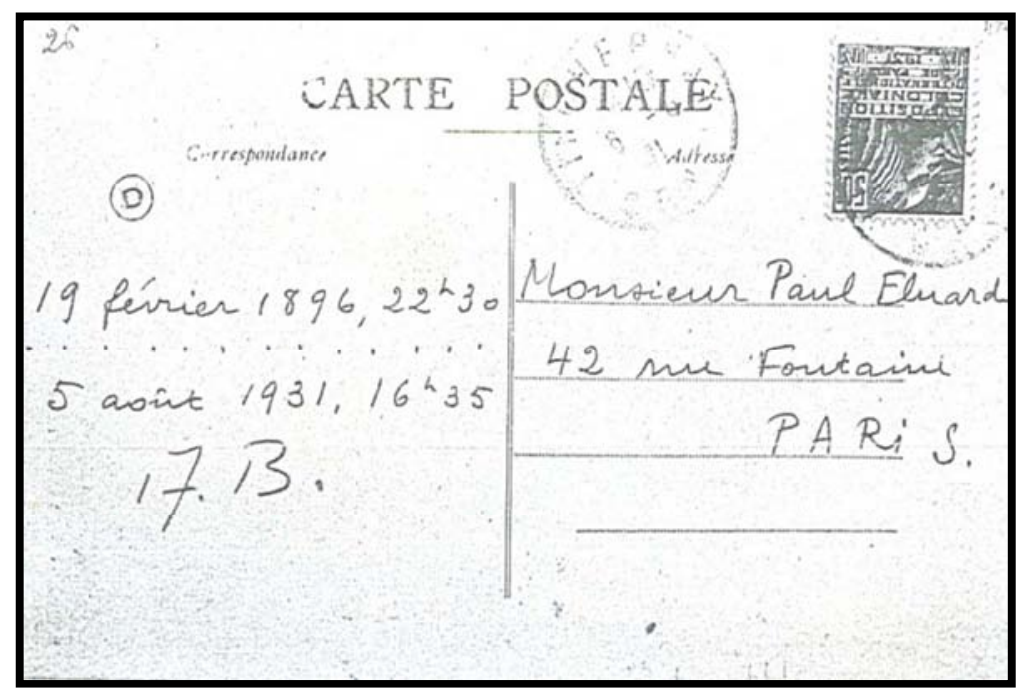

Figure 1. La carte postale de Tinchebray.

In the manuscript of Arcane 17, Breton notes the numbers 17 and 13, in which he sees the equivalent of his initials. In the title of his article "Par un après-midi très froid des premiers jours de 1713 ou le monde tel qu'il est [17]“ Paul Éluard also refers to it. Maxime Alexandre will write in his Mémoires d'un surréaliste about Breton's habit, which is part of the custom:

"Il y avait toujours à sa porte (42, rue Fontaine), une ardoise d'écolier, avec un petit morceau de craie attaché par une ficelle. Sur l'ardoise, qu'il y eût laissé un message annonçant son absence ou non, on lisait ses initiales, dessinées de manière à former le chiffre 1713 , A étant le 17 , $\mathrm{B}$ le 13. On pense bien que Breton se préoccupait de la signification de cette date par rapport à sa vie [18]."

Presented in 1942, at the exhibition of the Peggy Guggenheim gallery, the poem-object: "Portrait of the actor A. B." "Figure 2" also refers to the number 1713. According to Breton, the poem-object consists in combining the resources of poetry and plastic and observing their power of mutual exaltation. The initial project of the author of this 
poem-object is to clarify, as far as he is concerned, a particular graphological problem. This problem, this graphic equivalence, for Breton, is the number 1713 (the 17 is obtained by adding the digits of his date of birth: February 18, 1896).

"Ayant observé que, réduite aux initiales, sa propre signature simule le nombre 1713, il a été amené intuitivement à ne voir dans ce nombre qu'une date de l'histoire européenne et a eu la curiosité de relever les événements saillants que cette date peut marquer (il se pourrait en effet que l'un au moins de ces événements fût de nature à entraîner pour lui la fixation inconsciente à un temps révolu, voire l'identification avec ce temps) [19]."

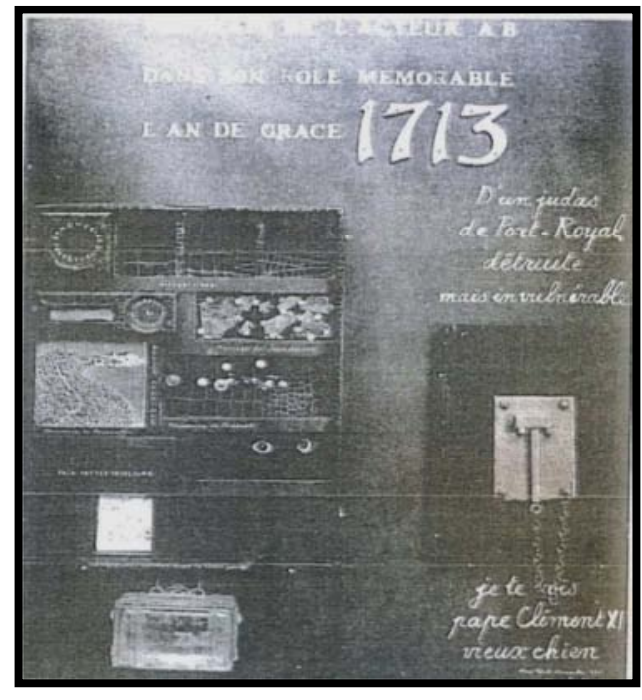

Figure 2. André Breton, Poème-objet. 1941.

Intrigued since 1920 by the similarity of his initials A. B. with the date 1713, Breton enumerated the events which, during this year established a network of associations related to its existence.

Breton really sees in this number a date of European history which, at the same time, intrigues and can easily bring it to the unconscious domain and provoke in itself the assimilation with this time. Breton gives us the description of this identification:

1 for the left box, Breton offers us his explanation: "Perpetual ephemerides: empty niches and transmission belts" in [19]. For Breton, there is a dialectical aspect of time: "the actors disappear, but their message reaches us" in [19]. The brown belt acts as an intermediary to ensure the communication of movement between the two wheels.

"Quelles traces des passages individuels ? On retient le mariage de Saunderson, mathématicien aveugle, inventeur d'une machine à calculer sans voir, décrite par Diderot (Lettre sur les aveugles) et esquissée dans la case centrale de droite pour les chiffres $0,1,2$ et 3 [...], la naissance de Vaucanson, constructeur d'automates célèbres parmi lesquels un canard à demi légendaire dont on conte qu'il mangeait et digérait [...], la naissance, enfin, de Diderot lui-même. Sur le terrain des événements militaires impliquant la considération de l'état social, 1713 est l'année de la paix d'Utrecht, passablement désastreuse pour la France, qui met fin à la guerre de la Succession d'Espagne; Paix pattes de velours, par l'intermédiaire de l'expression "faire patte de velours" qui veut dire rentrer ses griffes, et Utrecht, célèbre universellement par ses velours, engendrent ici un chat qu'il n'est pas trop difficile d'apercevoir dans les six cases inférieures; tête et corps, pattes, queue. Les yeux, en réalité, sont ceux d'un lynx, sans doute parce qu'un aveugle vient de passer. Les diplomates s'arrêtaient devant la Kleine Poortje (ou la Petite Porte, nom d'une petite auberge d'Utrecht où, quelque soixante ans plus tôt, épris de la servante Annetje, s'était fixé, après d'étonnantes tribulations, l'esprit le plus attachant du XVII ${ }^{\mathrm{e}}$ siècle, le cardinal de Retz).

$2^{\circ}$ Valise inférieure. - Comme on devine à travers le verre trouble, elle permet de voyager à travers le temps.

$3^{\circ}$ Plaque de droite. - D'un judas de Port-Royal détruite mais invulnérable je te vois pape Cément XI [sic], vieux chien (sur le plan spirituel, c'est aussi en 1713 qu'est promulguée la bulle Unigenitus qui consacre le triomphe des jésuites sur les jansénistes, déboute par là de leurs plus hautes instances Pascal et Racine et ouvre une crise morale dont les effets sont peutêtre plus que jamais sensibles aujourd'hui. L'abbaye de PortRoyal, qui abritait le cœur du jansénisme, a été détruite sauvagement l'année précédente et son cimetière livré aux chiens. La plaque figure à la fois la bulle elle-même, la résistance invisible que certains lui opposent et le judas par lequel l'œil voit se dévider les circonstances historiques. Le parti pris à cet égard par l'auteur est rendu plus manifeste encore par l'expression l'an de grâce appliqué dans le titre à 1713 et par la dominante sombre de l'objet) [20]."

The birth certificate of Breton André Robert, "Figure 3" as an official act bears the date of February 19, 1896. Why does Breton change his date of birth? Why does he refer to February 18, 1896, which is in the sign of Aquarius (last day of the sign) when his date of birth is officially February 19, 1896? The arithmosophic calculation for these two dates has different values:

February $18,1896=17$

February 19, $1896=9$

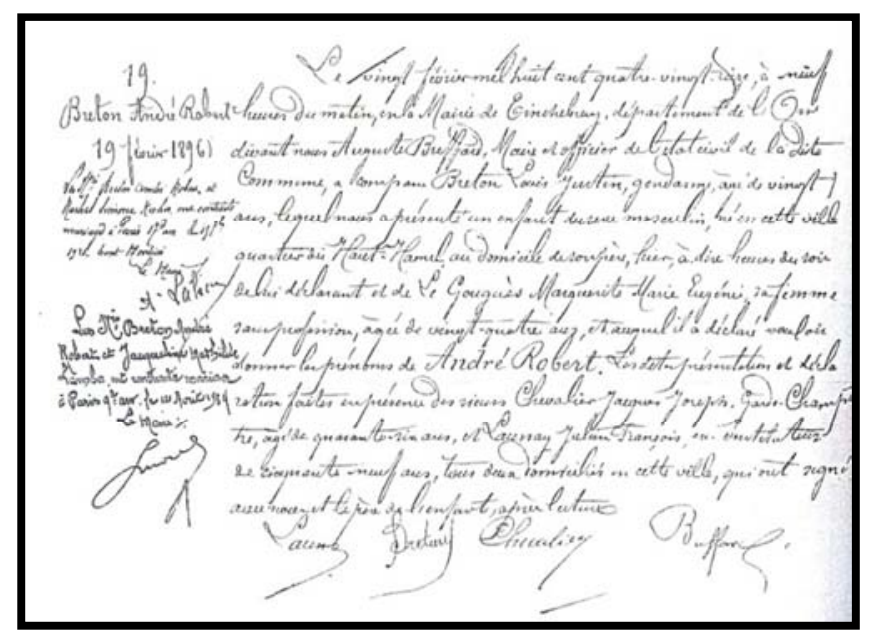

Figure 3. Acte de naissance de Breton André Robert, 19 février 1896; acte $n^{\circ} 19$. 
The exact version of a Breton-Fish, born on February 19, 1896, appears in his works first in Mont de piété (19131919). The prose poem $\hat{A g e}$ is dated February 19, 1916 and according to Breton himself, this date coincides exactly with his twentieth birthday.

In "Un Problème" of the Introduction au discours sur le peu de réalité (1925), Breton almost invites us to make a calculation: "eleven years and forty days" after January 10, 1925. It is indeed February 19, 1936, that is, Breton's fortieth birthday according to the formal birth certificate.

He states in the Manifeste du surréalisme: "POISSON SOLUBLE, n'est-ce pas moi le poisson soluble, je suis né sous le signe des Poissons et l'homme est soluble dans sa pensée [21] !“

But the second version, that of a Breton-Aquarius, born on February 18, 1896, appears in the insertion prayer of Point $d u$ jour (September 1934), "Figure 4" where it indicates the date of birth, the hour (around 8:30 p. m. ) and the detailed horoscope.

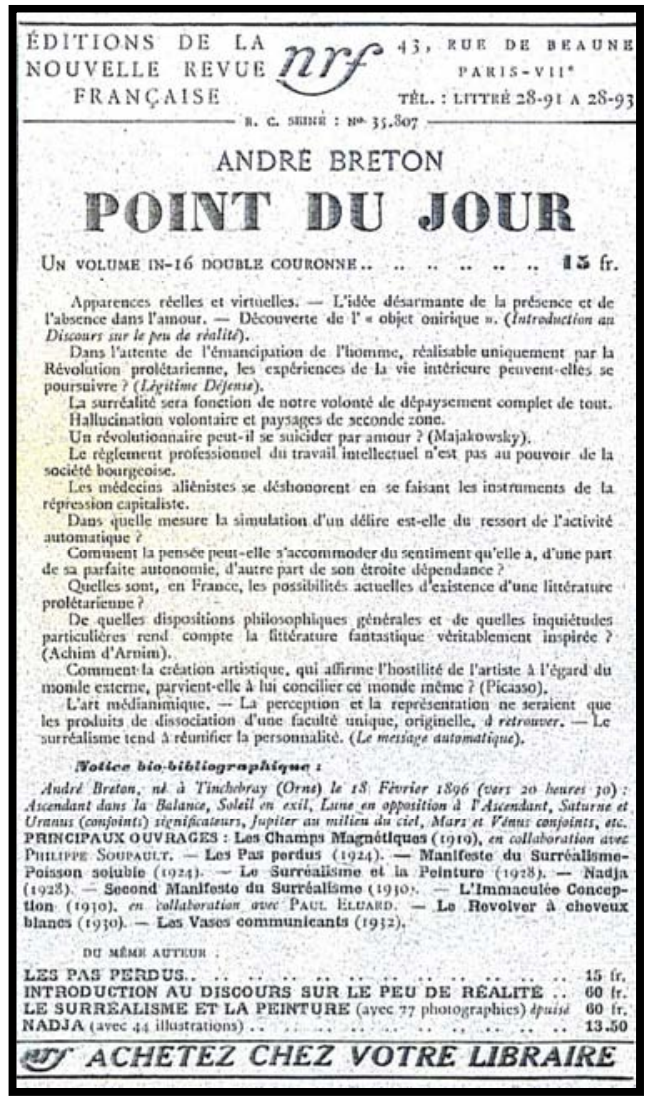

Figure 4. Point du jour.

Since 1934, Breton defends three formulas:

$\mathrm{AB}=1713$

André Breton $=$ February 18, $1896=$ mardi gras

February $18,1896=17$

The second part of Vases communicants, opened under the Nervalian sign of wandering and "sudden rapprochements, petrifying coincidences" [22], Breton analyses his dreams as well as his diurnal life, because in his eyes, it is equivalent to a waking dream. He relates in detail his day of April 21,
1931, but when we examine this text carefully we note: "Tuesday, April 21" [23], "Tuesday, April 20" [24] and "Tuesday, April 22" [25]. Only the first date is consistent with the calendar and context. In one case, Breton is wrong on the day of the month ( 20 put for 21$)$. In the other, he is mistaken by day (Tuesday set for Wednesday).

"The next evening, April 22... [26]", thus announces the second part of the third "ajour" of Arcane 17. However, since the day before was April 27, the dating is obviously incorrect. Breton is mistaken on the day of the month (22 put for 28). When one sees what value Breton gives to the number, the error of "April 22" can only be the result of a thoughtful process. In this third "ajour", the poet reports the hidden message of Jacques Halpern:

"Tour Saint-Jacques, le 21, 3 heures. [...] La jeunesse éternelle. "1808=17"; Naissance de Nerval. - Publication de Théorie des quatre mouvements et des destinées générales ${ }^{4}$.

Ma seule étoile vit..." [27]

The formula "1808 = 17" implicitly associates the destinies of Fourier, Nerval and Breton. Jean Richer [28] writes on arithmosophy in the article entitled "Dans la forêt des signes" and reveals that at the time of the third "ajour" (May 1947) Breton had made the following arithmosophic calculations on his date of birth and that from Nerval:

$18-2-1896=18+2+24=9+2+6=17$

$22-5-1808=4+5+17=4+5+8=17$ [29]

It is not surprising that, in Arcane 17, about the portrait of Nerval "Figure 5" published by Jean Richer, Breton speculates on the strange encounters of the numbers 17 and 13 and compares, earlier in the text, Hugo and Fabre d'Olivet, Nerval and Pythagoras, Baudelaire and Swedenborg, Rimbaud and the work of alchemy, Apollinaire, the Jewish Cabal and the novels of the cycle of Arthur.

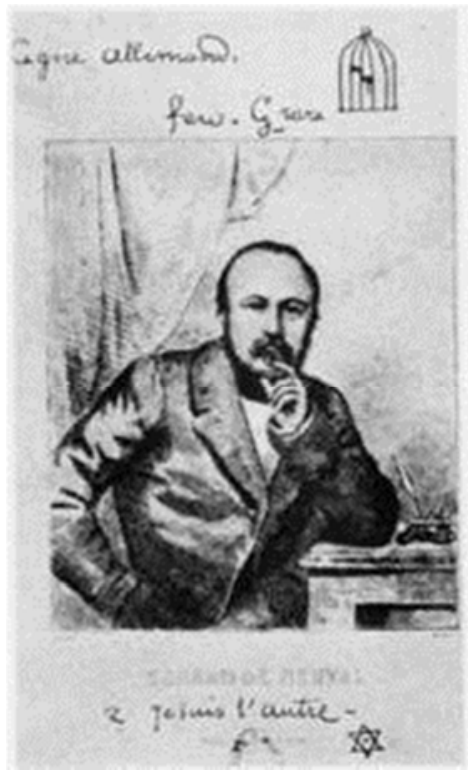

Figure 5. Gérard de Nerval.

\section{"[...] en marge supérieure, à gauche "Cigne allemand",}

4 The work of Charles Fourier was published in 1808. 
au centre "feu G rare", la dépendance de la lettre $G$ et de l'adjectif étant soulignée par un petit signe de liaison. Le passage du G au geai, [...] est clairement spécifié, à droite, par le dessin sommaire d'un oiseau en cage. Partant de ce G, je ne puis, quant à moi, m'empêcher de relever dans le portrait la curieuse position de l'index méditativement appuyé au menton et qui, dans la planche, tombe juste audessous de la lettre. Mais je doute que les familiers de l'œuvre de Rimbaud découvrent sans frémissement, en marge inferieure, les mots “Je suis l'autre” précédés d'un point d'interrogation et comme signés d'un hexagramme à point central. [...] je n'eus, guidé par l'exégèse de M. Jean Richer, aucune peine à me convaincre qu'ici, sur le plan symbolique pur, j'avais cheminé avec Nerval le long du sillon doré."

\section{Conclusion}

This article aims to show how Breton treats esoteric thought as the possibility of infinitely expanding the poetic field. Breton, wanting to free the expression of ideological shackles and making artistic expression the very substance of life, sees in esotericism the possibility of a deployment of reverie and poetic inspiration, but also an unlimited field for a total imaginary exploration.

The initials of his signature simulate the number 1713 , which allows him to form another perspective encompassing historical events that occurred in 1713. The content of the poem-object in Le Surréalisme et la peinture evokes about 1713: the marriage of the blind mathematician Saunderson, inventor of a calculating machine, the birth of Vaucanson and Diderot. Breton also retains the peace of Utrecht, Cardinal of Retz, the Unigenitus Bull of Pope Clement XI which presents the triumph of the Jesuits over the Jansenists, the destruction of the abbey of Port-Royal etc. In L'Imprononçable jour de ma naissance, 17 ndré 13 reton Georges Sebbag writes that all durations quoted in bulk are, in fact instructed by a primitive scene, the invention of Pascal's calculating machine. According to him, Pascal, the ancestor of Saunderson, discovers his arithmetic machine in 1642 and is interested in the principles of probability calculation. Between Pascal and Saunderson, intervenes a third mathematician. It was Jacques Bernouilli, born in 1654 and died in 1705. In 1713, appears the Ars conjectandi, Jacques Bernouilli's posthumous work, appeared, in which the author wanted to apply the calculation of probability to moral and economic sciences. We can suppose, moreover, how L'Art de conjecturer and this calculation of the future that the work proposes, could interest André Breton, inventor of "hasard objectif", to the highest degree. The obsessive reference to the date 1713 is also based on avoidances and a choice of precise references.

Thus, in his early works, contemporary works of Dadaist engagement, André Breton appears refractory to the dominant contemporary stereotypical representations of the eighteenth century. No less than his future Surrealist companions, André Breton is clearly a stranger to the Republican exaltation of the Enlightenment. The Revolution seems to seduce him only in its most radical and convulsive elements. The field of the eighteenth century seems to be just one of many, with a support for reverie, as evidenced by the complex play with the date 1713.

Gérard de Nerval's invocation is justified by the fact that he possesses wonderfully "l'esprit" of which the surrealists claim and the persistent vitality of an esoteric conception of the world and of human understanding.

\section{References}

[1] Patrick Lepetit, The Esoteric Secrets of Surrealism: Origins, Magic, and Secret Societies, Inner Traditions, Rochester, Vermont, Toronto, Canada, 2014, pp. 85-86.

[2] Richard Danier, L'Hermétisme alchimique chez André Breton; Interprétation de la symbolique de trois auvres du poète, préface de Patrick Rivière, Villeselve, Collection dirigée par Philippe Pissier, Éditions Ramuel, 1997, p. 153.

[3] Richard Danier, L'Hermétisme alchimique chez André Breton; Interprétation de la symbolique de trois ouvres du poète, préface de Patrick Rivière, Villeselve, Collection dirigée par Philippe Pissier, Éditions Ramuel, 1997, p. 158.

[4] Suzanne Lamy, André Breton. Hermétisme et poésie dans Arcane 17, Bibliothèque Nationale du Québec, Les Presses de l’Université de Montréal, 1977, p. 31.

[5] Laffont-Bompiani, Dictionnaire des œuvres de tous les temps et tous les pays ( 7 tomes), Paris, Robert Laffont-Bompiani, 1989, p. 34.

[6] Laurent Jenny, "La surréalité et ses signes narratifs", in Poétique n¹6, 1973, p. 449.

[7] S. Lamy, André Breton. Hermétisme et poésie dans Arcane 17, op. cit., p. 21.

[8] Umberto Eco, La Structure absente; Introduction à la recherche sémiotique, Paris; Mercure, 1972, p. 350.

[9] Roland Barthes, "Introduction à l'analyse structurale des récits", Communications, $\mathrm{n}^{\circ} 8$, Recherches sémiologiques; l'analyse structurale du récit, 1966, p. 4, note 1 .

[10] S. Lamy, André Breton. Hermétisme et poésie dans Arcane 17, op. cit., p. 21.

[11] Voir. M Riffaterre, "La Métaphore filée dans la poésie surréaliste”, Langue française, n³, 1969.

[12] André Breton, Euvres complètes, t. III; Arcane 17 enté d'Ajours, Paris, Éditions Gallimard, Bibliothèque de la Pléiade, NRF, 1999, p. 113.

[13] André Breton, Euvres complètes, t. III; Arcane 17 enté d'Ajours, Paris, Éditions Gallimard, Bibliothèque de la Pléiade, NRF, 1999, p. 37.

[14] André Breton, Euvres complètes, t. III; Entretiens 1913-1952 (XV.-DE QUELQUES ESPÉRANCES ABUSIVES.-À PARIS LE SURÉALISME DOIT DÉJOUER DIVERSES MANEUVRES D'OBSTRUCTION.-GAGES DE SA VITALITÉ.), op. cit., p. 558. 
[15] André Breton, Euvres complètes, t. III; Entretiens 1913-1952 (XV.-DE QUELQUES ESPÉRANCES ABUSIVES.-À PARIS LE SURÉALISME DOIT DÉJOUER DIVERSES MANEUVRES D'OBSTRUCTION.-GAGES DE SA VITALITÉ.), op. cit., pp. 558-559.

[16] André Breton, Euvres complètes, t. IV; Perspective cavalière (Le Surréalisme et la Tradition), Paris, Éditions Gallimard, Bibliothèque de la Pléiade, NRF, 2008, p. 946. This is the answer to an inquiry: "How can surrealism, through you, join the tradition (metaphysical and religious) through René Guénon that you quoted recently? from Jean Chevalier and Claude Galocher.

[17] Minotaure, n5, 5, mai 1934, p. 17.

[18] Maxime Alexandre, Mémoires d'un surréaliste, La Jeune Parque, 1965, p. 106.

[19] André Breton, CEuvres complètes, t. IV; Le surréalisme et la peinture; IV. Environs (Du poème-objet), p. 693.

[20] André Breton, Euvres complètes, t. IV; Le surréalisme et la peinture; IV. Environs (Du poème-objet), p. 693-694.

[21] André Breton, Euvres complètes, t. I; Manifeste du surréalisme, Paris, Éditions Gallimard, Bibliothèque de la Pléiade, NRF, 1988, p. 340.

[22] André Breton, Euvres complètes, t. I; Nadja, op. cit., p. 651.
[23] André Breton, Euvres complètes, t. II; Les Vases communicants, II, Paris, Éditions Gallimard, Bibliothèque de la Pléiade, NRF, 1992, p. 167.

[24] André Breton, CEuvres complètes, t. II; Les Vases communicants, II, Paris, Éditions Gallimard, Bibliothèque de la Pléiade, NRF, 1992, p. 171.

[25] André Breton, CEuvres complètes, t. II; Les Vases communicants, II, Paris, Éditions Gallimard, Bibliothèque de la Pléiade, NRF, 1992, p. 174.

[26] André Breton, Euvres complètes, t. III; Arcane 17 enté d'Ajours, op. cit., p. 110.

[27] André Breton, Euvres complètes, t. III; Arcane 17 enté d'Ajours, op. cit., pp. 108-113.

[28] Jean Richer (1915-1992), author of several works concerning Gérard de Nerval and Arithmosophy. (Gérard de Nerval et les doctrines ésotériques, Le Griffon d'or, 1947; Aspects ésotériques de l'ouvre littéraire; Saint-Paul, Jonathan Swift, Jacques Cazotte, Ludwig Tieck, Victor Hugo, Charles Baudelaire, Rudyard Kipling, O. V. de L. Milosz, Guillaume Apollinaire, André Breton, Dervy Livres 1980; Olivier Encrenaz et Jean Richer, Vivante étoile. Michel-Ange, Gérard de Nerval, André Breton, Paris, Minard, Archives des lettres modernes, $\mathrm{n}^{\circ} 127,1971$.)

[29] Jean Richer, André Breton et le mouvement surréaliste, NRF, $\mathrm{n}^{\circ} 172$, Gallimard, avril 1967, pp. 826-832. 